\title{
THE CREDIT RATING INDUSTRY
}

$\begin{array}{llll}\text { A. INTRODUCTION } & 1.01 & \text { 3. The reputational capital of CRAs } & 1.30 \\ \text { 1. The 'gatekeeper' function } & 1.07 & \text { 4. Structure of the book } & 1.53 \\ \text { 2. Role of CRAs in the financial markets } 1.17 & & \end{array}$

\section{A. INTRODUCTION}

1.01 In the aftermath of the global financial crisis, credit rating agencies (CRAs) were blamed for exacerbating systemic risk because of the role they played in the financial markets as an information intermediary between investors and issuers. ${ }^{1}$ CRAs are private companies which provide public opinions as to the creditworthiness of debt instruments (bonds and commercial paper) and are mainly financed by commission fees. ${ }^{2}$ Ratings are based on issuers' public information and are taken into account in determining such matters as trends and investment decisions. ${ }^{3}$ Ratings estimate the risk in relative rank order, but they do not predict credit risks in terms of a specific frequency of default or loss, ${ }^{4}$ as observed 'ratings are forward-looking statements which represent the raters' judgement of the creditworthiness of an entity'. ${ }^{5}$

1 Andreas Kruck, 'Asymmetry in Empowering and Disempowering Private Intermediaries: The Case of Credit Rating Agencies' (2017) 670(1) The ANNALS of the American Academy of Political and Social Science 144.

2 As defined by Section 3(a) (60) of the US Credit Rating Agency Reform Act 2006, credit rating means 'an assessment of the creditworthiness of an obligor as an entity or with respect to specific securities or money market instruments'. See also Article 3 of Regulation (EC) No 1060/2009 of the European Parliament and of the Council of 16 September 2009 on credit rating agencies (OJ 2009 L 302, p. 1): (a) 'credit rating' means an opinion regarding the creditworthiness of an entity, a debt or financial obligation, debt security, preferred share or other financial instrument, or of an issuer of such a debt or financial obligation, debt security, preferred share or other financial instrument, issued using an established and defined ranking system of rating categories; (b) 'credit rating agency' means a legal person whose occupation includes the issuing of credit ratings on a professional basis.

3 Arturo Estrella et al., 'Credit Ratings and Complementary Sources of Credit Quality Information', BCBS Working Papers No 3, 11, where it is pointed out that 'credit rating agencies play a useful role by collecting information about a firm and sharing it with a large number of investors'.

4 Damien Fennel and Andrei Medvedev, 'An Economic Analysis of Credit Rating Agency Business Models and Ratings Accuracy' (November 2011) Financial Services Authority, Occasional Paper Series No 41, 9-10.

5 Arad Reisberg, 'The Future Role of Credit Rating Agencies in Contemporary Financial Markets - A Theoretical Perspective' in Dan Prentice and Arad Reisberg (eds), Corporate Finance Law in the UK and EU (Oxford: Oxford University Press 2011) 173. 
CRAs provide an assessment of the ability of issuers to meet their debt obligations through information monitoring services that promote liquid markets. ${ }^{6}$ Further, CRAs are defined as 'certification intermediaries'7 or 'reputational intermediaries'. ${ }^{8}$ On this view, it can be argued that CRAs are reputational intermediaries providing certification services to investors, where these services regularly consist of monitoring and assessing a company's creditworthiness. CRAs provide two essential services: (1) solicited ratings, where the issuer requests a rating for its securities in return for a fee; and (2) unsolicited ratings, which are based only on publicly available information and no fee is paid.

The CRAs' business model, whereby the rating agencies are paid by the self-same entities whose products they are rating, is often referred to as the 'issuer-pays' model. This system was adopted by the main CRAs (Moody's, Standard \& Poor's (S\&P's), Fitch IBCA, Duff and Phelps Credit Rating Co.) in the early 1970s. As a result, the main credit-rating firms changed their business models from the 'investor-pays' model established by John Moody in 1909 to an 'issuer-pays' model. ${ }^{9}$ It is instructive that the entities whose products are being rated are the very parties who are actually paying for their products to be rated. The CRA is paid by the party wishing to be assessed but its relative credibility stems from the fact that it is in effect pledging a reputational capital that it has built up over many years of performing similar services for numerous clients' ${ }^{10}$

The International Organization of Securities Commissions (IOSCO) defines

a credit rating as 'an opinion regarding the creditworthiness of an entity, a

6 John Kiff, Allison Holland, Michael Kisser, Sylwia Nowak, Samer Saab, Liliana Schumacher, Han van der Hoorn and Ann-Margret Westin, 'The Uses and Abuses of Sovereign Credit Ratings' in IMF World Economic and Financial Surveys. Global Financial Stability Report. Sovereigns, Funding and Systemic Liquidity (October 2010) 88-89.

7 Stephen Choi, 'Market Lessons for Gatekeepers' (1998) 92(3) Northwestern University Law Review 924. See also Jonathan Macey, 'Wall Street Versus Main Street: How Ignorance, Hyperbole, and Fear Lead to Regulation' (1998) 65(4) University of Chicago Law Review 1500.

8 Reiner H. Kraakman, 'Corporate Liability Strategies and the Costs of Legal Controls' (1984) 93(5) Yale Law Journal 895-96; see also Reiner H. Kraakman, 'Gatekeepers: The Anatomy of a Third-Party Enforcement Strategy' (1986) 2(1) Journal of Law, Economics, and Organization 54. From this perspective, the CRAs are repeat intermediaries who provide certification or verification services to investors. The issuer uses the reputational intermediary to send a credible signal that its securities are of above average quality in order that it can pay a below average interest rate. See on this point John C. Coffee Jr., Gatekeepers: The Professions and Corporate Governance (Oxford: Oxford University Press 2006) 288.

9 The main CRAs nowadays are Moody's Investors Service, Standard \& Poor's Ratings Services and Fitch Ratings.

10 John C. Coffee Jr., 'Understanding Enron: “It's About the Gatekeepers, Stupid” (2002) 57(4) The Business Lawyer 1405. 
credit commitment, a debt or debt-like security or an issuer of such obligations, expressed using an established and defined ranking system; they are not recommendations to purchase, sell, or hold any security. ${ }^{11}$ According to this definition, credit rating opinions do not constitute recommendations for investors but simply opinions or views evaluating the likelihood of timely repayment.

1.05 Nonetheless, ratings do provide valuable information regarding decisions made by investors and regulators. However, the exercise of freedom of expression carries with it duties and responsibilities which may be subject to restrictions such as liability for false and misleading misrepresentations or gross negligence prescribed by law as necessary for the prevention of market disorder. ${ }^{12}$ The question is whether a 'mere opinion' can be considered to carry with it an exemption from any responsibilities. If this notion of CRAs as providers of 'mere opinions' is accepted, CRAs cannot be held liable for losses arising from detrimental reliance on their ratings. ${ }^{13}$

1.06 A question that needs to be addressed is whether there is any scope for considering an opinion-on which investors and consumers have placed reliance-as carrying liability. In other words, can CRAs be liable for investors' losses on the basis that the investors relied on the ratings. In 2009, the District Court of New York held that 'ratings on notes sold privately to a select group of investors were not matters of public concern deserving of traditionally broad protection under the First Amendment of the US Constitution'. ${ }^{14}$ This ruling provided a new perspective on the accountability of CRAs because it held that ratings of securities that were distributed to a limited number of investors did not deserve the same free-speech protection as more general ratings of corporate bonds that were widely disseminated. ${ }^{15}$ In their defense, CRAs frequently argue that they are not party to any contractual relationship

11 IOSCO Technical Committee, 'Code of Conduct Fundamentals for Credit Rating Agencies' (December 2004) 3.

12 In such case, it is necessary to draw a parallel with the law of defamation, where the right to freedom of expression has to be balanced against the right to one's reputation and family life (privacy) as well as data protection. Defenses under English law include justification (i.e. what you are saying is true) and freedom of speech may be the subject of certain privileges in the public interest. Otherwise, damages may be payable.

13 Gregory Husisian, 'What Standard of Care should Govern the World's Shortest Editorials?: An Analysis of Bond Rating Agency Liability' (1990) 75(2) Cornell Law Review 454-55. The author argues that 'ratings are editorial opinions, published in letter form'.

14 Abu Dhabi Commercial Bank et al. v Morgan Stanley \& Co., et al. [2009] District Court of New York, No 08-7508. This is a relevant case in which a US Court has not held that agency ratings constitute protected commercial speech under the First Amendment.

15 ibid 33. In particular, the Court held that 'where a rating agency has disseminated their ratings to a select group of investors rather than to the public at large, the rating agency is not afforded the protection of the First Amendment'. 
with investors but only with issuers. As a result, the main relationship is between the CRAs and the companies that request the security rating. Therefore, it is necessary to take account of the CRAs' liability regime, particularly the scholarly debate about the responsibility of raters for inaccurate and misleading assessments.

This part provides an overview of the CRAs' activities, as well as a map of the role played by ratings in the financial markets. It explores the CRA industry by taking into consideration the importance of improving disclosure and transparency ratings. This reflection identifies some key aspects, notably the extent to which the ratings industry can reduce conflicts of interest and investors' over-reliance. It further addresses the need to enhance the organizational and governance rules of CRAs.

\section{The 'gatekeeper' function}

Generally speaking, CRAs play the role of a driver of the securities market and are 'hardwired' into the regulatory system. In particular, CRAs provide advice for investors, who are often subject to restrictions as to their ownership of debt of a certain grade. The 2007-09 financial crisis gave rise to an expansion of the CRAs' power worldwide and revealed not only market and regulatory failure, but also the failure of the current laws governing credit ratings. ${ }^{16}$

Risk management failed to recognize the powerful function of ratings and

their potential systemic effects on financial markets as the global crisis confirmed that there was an overdependence on CRAs. ${ }^{17}$ Specifically, CRAs were accused of determining a systemic risk because of the scant incentive for them to perform their screening accurately, while policymakers, institutional investors and global regulators underestimated the functions of the risks stemming from CRAs. The magnitude of the systemic risk brought about by ratings in the banking and securities system represents a threat to financial stability. This is because it results in a distortion in the structure of the securities market (i.e. falls in market value driven by downgrades, lack of transparency and the capacity to cause herding among investors). ${ }^{18}$

16 Nicholas Dorn, 'Policy Stances in Financial Market Regulation: Market Rapture, Club Rules or Democracy?' in Kern Alexander and Niamh Moloney (eds), Law Reform and Financial Markets (Cheltenham: Edward Elgar Publishing 2011) 45-46.

17 Amadou N.R. Sy, 'The Systemic Regulation of Credit Rating Agencies and Rated Markets' (2009) IMF Working Paper 129, 29.

18 Iain MacNeil, 'Credit Rating Agencies: Regulation and Financial Stability' in Thomas Cottier, Rosa M. Lastra and Christian Tietje (eds), The Rule of Law in Monetary Affairs (Cambridge: Cambridge University Press 2014) 189. 
In essence, investors in securities misunderstood the key role played by credit ratings in the investment decisions of financial participants and the widespread use of 'ratings triggers' in private contracts as discussed in the next part of this book. ${ }^{19}$ The power of CRAs has more to do with moral suasion tools than with governmental influence because 'this informal power becomes formal only when politicians make it so. Regulators naturally milk the agencies when things are going well and scapegoat them when things are bad'. ${ }^{20}$

1.09 The securities market also revealed that CRAs have led to tighter oversight of gatekeepers, i.e. 'independent professionals who pledge their reputational capital to protect the interests of dispersed investors who cannot easily take collective action'21 (for instance, private parties which act to facilitate access to the securities market by providing financial services to investors), while also revealing the limits of regulators' power. The ratings had become essential to any transaction and regulatory intervention relied on the reputational capital of CRAs. For instance, buy-side firms such as pension funds, mutual funds and insurance companies made huge use of ratings assessments in order to ensure compliance with statutory laws. ${ }^{22}$

In this respect, ratings had become a valuable benchmark in the banking and securities markets because of their use in bank-capital regulation for macroprudential supervision and the control of systemic risks. ${ }^{23}$ Indeed, the former Financial Services Authority (now the Financial Conduct Authority) noted ${ }^{24}$ that regulators placed significant reliance on external ratings as part of the

19 Rating triggers are contractual provisions that give counterparties and lenders the right to terminate the credit availability, accelerate credit obligations, or have the borrower post collateral in the event of specified rating actions, such as where the rating of the borrower's fixed-income securities falls below a certain level. See Committee of European Securities Regulators, 'CESR's Technical Advice to the European Commission on Possible Measures Concerning Credit Rating Agencies' (March 2005) 38 and 87-93.

20 Christopher Caldwell, 'An Inconvenient Truth: The Power of Moral Suasion' Financial Times (London, 9 December 2011)

21 John C. Coffee Jr., 'Gatekeeper Failure and Reform: The Challenge of Fashioning Relevant Reforms' in Klaus J. Hopt, Eddy Wymeersch, Hideki Kanda and Harald Baum (eds), Corporate Governance in Context: Corporations, States, and Markets in Europe, Japan and the US (Oxford: Oxford University Press 2005) 605-06; see also John C. Coffee Jr., 'The Acquiescent Gatekeeper: Reputational Intermediaries, Auditor Independence and the Governance of Accounting' (2001) Columbia Law School Working Paper No 191, 2.

22 Securities and Exchange Commission, 'Report on the Role and Function of Credit Rating Agencies in the Operation of the Securities Markets. As Required by Section 702(b) of the Sarbanes-Oxley Act of 2002' (January 2003) 28.

23 Kern Alexander, 'The Risk of Ratings in Bank Capital Regulation' (2014) 25(2) European Business Law Review 295-96. It is observed that 'central banks used credit ratings in their open market and liquidity operations to determine the type of bonds and other debt instruments they would take as collateral and the margin or haircut applied to such collateral when purchasing bonds or lending cash to participating financial institutions' (at 298).

24 Financial Services Authority, 'A Regulatory Response to the Global Banking Crisis', Discussion Paper No 09/2, March 2009, at para 1.57 . 
calculation of capital requirements in accordance with the Capital Requirements Directive (CRD). ${ }^{25}$

The ratings are involved in the regulatory standards of capital requirements (especially in the so-called pillar I 'Minimum Capital Requirements' of the Basel II Accord) and in setting capital models for credit risk. ${ }^{26}$ CRAs play an important role in the capital adequacy regulation of banks and in the determination of regulatory capital through the 'Standardized Approach'. ${ }^{27}$

The Basel III framework assessed measures to mitigate the reliance on external ratings of the Basel II regime. These measures included requirements for banks to perform their own internal assessments of externally-rated securitization exposures. ${ }^{28}$ It has been observed that it seems paradoxical that the regulators, on the one hand, criticize credit rating agencies for their role in the financial crisis and subject them to regulatory control but, on the other hand, leave them the key to the financial markets'. ${ }^{29}$

The increasing role of CRAs in the financial markets can be explained by the reputational incentives and regulatory license model. ${ }^{30}$ The former only works if the intermediary has gained sufficient reputational capital to be trusted by investors, ${ }^{31}$ while the latter functions by reducing the issuer's costs, or the costs of financial intermediaries, allowing CRAs to sell regulatory licenses to enable such persons to avoid these costs. ${ }^{32}$ As Partnoy observed, 'the rating agencies

25 Directive 2013/36/EU of the European Parliament and the Council of 26 June 2013 on access to the activity and the prudential supervision of credit institutions and investment firms, amending Directive 2002/87/EC and repealing Directives 2006/48/EC and 2006/49/EC_Capital Requirements Directive IV (OJ 2013 L 176, p. 338).

26 Howell E. Jackson, 'The Role of Credit Rating Agencies in the Establishment of Capital Standards for Financial Institutions in a Global Economy' in Eilís Ferran and Charles A.E. Goodhart (eds), Regulating Financial Services and Markets in the Twenty First Century (Oxford: Hart Publishing 2001) 315-22. See also Rolf H. Weber and Aline Darbellay, 'The Regulatory Use of Credit Ratings in Bank Capital Requirement Regulations' (2008) 10(1) Journal of Banking Regulation 4-5.

27 Deniz Coskun, 'Credit-rating Agencies in the Basel II Framework: Why the Standardized Approach is Inadequate for Regulatory Capital Purposes' (2010) 25(4) Journal of International Banking Law and Regulation 157-58.

28 Basel Committee on Banking Supervision, 'Basel III: A Global Regulatory Framework for More Resilient Banks and Banking Systems’ (June 2011) 4.

29 Jan Oster, 'Who Rates the Raters? The Regulation of Credit Rating Agencies in the EU' (2010) 17(4) Maastricht Journal of European and Comparative Law 374.

30 Frank Partnoy, 'Barbarians at the Gatekeepers?: A Proposal for a Modified Strict Liability Regime' (2001) 79(2) Washington University Law Quarterly 494. Partnoy observes that 'a good reputation is valuable in transacting with other parties, and reputational capital enables parties to use trust to reduce the costs of transacting'.

31 Douglas W. Diamond, 'Reputation Acquisition in Debt Markets' (1989) 97(4) Journal of Political Economy 829-32.

32 Coffee Jr. (n 8) 288. 
have evolved from information providers to purveyors of regulatory licenses'. ${ }^{33}$ Specifically, securities regulation has increasingly relied on credit ratings and the credit rating agencies sector.

1.12 The regulators have used credit ratings in a variety of ways, for instance to assess the sovereign debt of countries, and have conferred on CRAs some 'regulatory licenses'. Such 'licenses' granted to companies and financial institutions the right to be in compliance with regulation. ${ }^{34}$ In this regard, 'regulatory licenses, and the behavioural overdependence on ratings that followed them, ultimately led to the creation and growth of the financial instruments at the core of the recent crisis'. ${ }^{35}$ The benefits associated with these regulatory licenses stem from securities laws, self-regulatory principles and uncertain court decisions. ${ }^{36}$ This scenario allows CRAs to circumvent the rules and avoid liability for misrepresentations or misconduct and, most importantly, any monitoring of their assessments. ${ }^{37}$

1.13 Ratings downgrades can trigger sales of certain financial products, thus highlighting the agencies' powerful role. These regulatory licenses allow CRAs to engage in dubious practices, including omissions and misleading opinions, as for instance in the Enron case. ${ }^{38}$ In sum, investors use ratings to make decisions about the credit risk of fixed-income securities and financial

33 Frank Partnoy, 'Rethinking Regulation of Credit-rating Agencies: An Institutional Investor Perspective' (2010) 25(4) Journal of International Banking Law and Regulation 188.

34 Reisberg (n 5) 179.

35 Frank Partnoy, 'Historical Perspectives on the Financial Crisis: Ivar Kreuger, the Credit-Rating Agencies, and Two Theories about the Function, and Dysfunction, of Markets' (2009) 26(2) Yale Journal on Regulation 442-43.

36 Frank Partnoy, 'The Siskel and Ebert of Financial Markets?' Two Thumbs Down for the Credit Rating Agencies' (1999) 77(3) Washington University Law Quarterly 623. The author argues that 'credit ratings are valuable not because they contain valuable information, but because they grant issuers regulatory licenses; a good rating entitles the issuer (and the investor in a particular issue) to certain advantages related to regulation' (at 681). Partnoy also observes that rating agencies sell information and survive based on their ability to accumulate and retain reputational capital. But once regulation is passed that incorporates ratings, rating agencies begin to sell not only information but also the valuable property rights associated with compliance with that regulation (at 682).

37 Coffee Jr. (n 8) 288. Coffee points out that 'the core idea behind the regulatory license is that regulation imposes costs which a favourable rating can reduce'. He states that 'a rating enables issuers to escape costly regulatory burdens or prohibitions to which they would otherwise be subject; or portfolio managers and institutional investors gain legal protection by virtue of such a credit-rating, because it insulates them from potential claims that they breached their fiduciary duties to investors in buying or holding the security'.

38 John C. Coffee Jr., 'What Caused Enron? A Capsule Social and Economic History of the 1990s' (2004) 89(2) Cornell Law Review 287-97. Coffee observes that the failure of the gatekeepers to detect Enron's collapse can be explained by the 'general deterrence' and 'bubble market' hypotheses. The first focuses 'on the decline in the expected liability costs that faced auditors who were considering whether or not to acquiesce in aggressive accounting policies favoured by managers'. The second focuses on the fact that-in an atmosphere of market euphoria - 'gatekeepers have less relevance and, consequently, reduced leverage with their clients'. See also Deniz Coskun, 'Credit Rating Agencies in a Post-Enron World: Congress Revisits the NRSRO Concept' (2008) 9(4) Journal of Banking Regulation 266-69. 
regulators use credit ratings to increase the monitoring of the risk of investments held by regulated entities.

Ratings are, however, also used by regulators (a) to determine when particular investment products can be sold to the public and (b) as a diversification tool to manage institutional investment. This means that the market price is influenced by rating pronouncements and CRAs' opinions that can affect financial confidence. It has been argued that 'the success of debt-raising by an issuer depends on the rating of the debt, with the rating a prerequisite which determines the interest rate offered and the cost of capital'. ${ }^{39}$

Notwithstanding this, as intermediaries, credit ratings should profit from protecting investors because they manage 'market information', which is generally considered to be a public good. ${ }^{40}$ In this light, ratings can be viewed as a public good because the provision of financial information can disclose information that benefits the public. ${ }^{41}$ Consequently, CRAs are trusted fiduciaries and mainstays of the financial community. As Strier noted, in bond ratings, the rating agencies are the key gatekeepers, in whom the trust of the investing public is reposed; public trust in any corporate gatekeeper is founded upon faith in its corporate governance apparatus'. ${ }^{42}$

In the aftermath of the global financial crisis, confidence in the rating agencies to 'get it right' was shaken by a growing amount of criticism and controversy. ${ }^{43}$ At the same time, the integrity of the CRAs' activity is threatened by the demands of winning and retaining clients in the more lucrative consultancy business.

In this respect, the modus operandi of CRAs raises major questions. As stated earlier, the relevance of this lies in the fact that credit ratings affect market confidence and influence investors' decisions and their expectations. For this reason, it is assumed that CRAs represent a potential distortion-in terms of

39 Niamh Moloney, EC Securities Regulation (2nd edn, Oxford: Oxford University Press 2008) 689.

40 Stephen Choi, 'A Framework for the Regulation of Securities Market Intermediaries' (2004) 1(1) Berkeley Business Law Journal 48.

41 It is generally considered in the economic literature that 'a public good is one where the consumption of the good by one individual in no way prevents others consuming the good or diminishes their enjoyment of it'. In other words, a public good is one where there is no rivalry and non-exclusion in consumption. See David M. Kreps, A Course in Microeconomic Theory (London: Harvester Wheatsheaf 1990) 168.

42 Franklin Strier, 'Rating the Raters: Conflicts of Interest in the Credit Rating Firms' (2008) 113(4) Business and Society Review 539.

43 John Patrick Hunt, 'Credit Rating Agencies and the "Worldwide Credit Crisis": The Limits of Reputation, the Insufficiency of Reform, and a Proposal for Improvement' (2009) 1 Columbia Business Law Review 112-14. See also Efraim Benmelech and Jennifer Dlugosz, 'The Alchemy of CDO Credit Ratings' (2009) 56(5) Journal of Monetary Economics 630-33. 
market failure ${ }^{44}$-for the securities industry. In this way, the research aims to show the importance for CRAs in maintaining investor protection. Consequently, the analysis is based on the assumption that CRAs should improve the incentives to supply complete available information and promote fair competition.

1.16 In other areas, CRAs should enhance financial stability for market participants. It is plain that if a financial market is stable, everybody benefits. However, Turner warned that 'financial instability is driven by human myopia and imperfect rationality as well as by poor incentives, and because any financial system will mutate to create new risks in the face of any finite and permanent set of rules'. ${ }^{45}$ In light of these considerations, the development of CRAs and their influence on the decisions and expectations of financial participants underline the major issues concerning the internal governance of CRAs. Above all, the increased role played by CRAs in building market confidence and investors' belief in financial products represents the main challenge for regulators.

\section{Role of CRAs in the financial markets}

1.17 It is generally considered that CRAs play the role of 'financial gatekeepers' by giving an evaluation of the creditworthiness of securities products. This means that CRAs are entities established to measure the relative risk that a borrower will fail to meet its financial commitments, such as interest payments and repayment of principal on a timely basis. ${ }^{46}$

CRAs aspire to act as 'forecasters' with regard to the debt liability of the issuer and its probability of default. However, accuracy of forecasting is the key question of credit rating. ${ }^{47}$ However, the gatekeeper's function begs the question as to what kind of liability should be attached to ratings. It is instructive to observe that despite the criticism that has been levelled in various quarters on account of the effects of the recent downgrades, investors

44 Francis M. Bator, 'The Anatomy of Market Failure' (1958) 72(3) The Quarterly Journal of Economics 351, where market failure is defined as 'the failure of a more or less idealized system of price-market institutions to sustain "desirable" activities or to estop "undesirable” activities'.

45 Adair Turner, 'Reforming Finance: Are we Being Radical Enough?’, 2011 Clare Distinguished Lecture in Economics and Public Policy, Clare College, Cambridge, 18 February 2011.

46 Kiff et al. (n 6) 88.

47 According to Coffee, 'the accuracy of a credit rating is only demonstrated over the long-run, but the payment for it is made in the short-run. This mismatch can create agency problems, as the managers who determine the rating may expect (or intend) to be around at the end of the ratings cycle'. See John C. Coffee Jr., 'Ratings Reform: The Good, The Bad, and The Ugly' (2010) European Corporate Governance Institute, Law Working Paper No 145, 29. 
continue to choose the same CRA players, namely Standard \& Poor's, Moody's and Fitch. This raises an important concern about the significant reliance of investors and the weakness of 'reputational incentive theory'. ${ }^{48}$ Another relevant question is how to deal with the 'issuer-pays' business model of CRAs. This is, undoubtedly, the most critical aspect of the ratings industry because of the inherent risk of conflicts of interest. 49

CRAs' knowledge of the consequences of inaccurate prediction might be considered to be morally equivalent to knowingly publishing a misleading assessment. ${ }^{50}$ In order to eliminate or reduce this kind of risk there is a need for investors to refer to CRAs that are set up only for genuine insight or for customized analysis. The potential damage of publishing misleading assessments is inextricably intertwined with the problem of consumer protection and market confidence. ${ }^{51}$

The accuracy of CRAs' forecasting creates their reputation and provides a clear pattern for understanding predictions. Issuers pay for an objective prediction, while investors (or consumers) rely on an independent assessment. However, the predictions are only very rarely subjected to empirical verification, and when such verification is attempted, some of the predictions are shown to be unreliable. ${ }^{52}$ In the literature, it is asserted that the inaccuracy of rating is due to the existence of: (1) conflicts of interest; (2) the lack of proper competition; and (3) reluctance to make a disclosure, since a key feature of ratings is the provision of information. ${ }^{53}$ The central role of ratings is to

48 Tom Hurst, 'The Role of Credit Rating Agencies in the Current Worldwide Financial Crisis' (2009) 30(2) Company Lawyer 64.

49 As indicated, CRAs operate under an 'issuer-pays' model under which issuers request agencies to provide ratings which are a prerequisite for external debt financing.

50 Rolf Weber and Simone Baumann, 'Conflicts of Interest and Risk Management Practices in the CRA Industry' in Jan Kleineman, Lars Gorton and Aron Verständig (eds), Perspectives on Credit Rating Agencies (Stockholm: Författarna, Stockholm Centre for Commercial Law och Jure Förlag AB 2013) 290. The authors argue that in the ratings industry 'the issuer-pay business model is not considered to be problematic because the CRA would have much more to lose by endangering their reputation for objectivity than they would have to gain if they favor one single customer'. See also Steven L. Schwarcz, 'Private Ordering of Public Markets: The Rating Agency Paradox' (2002) 1(1) University of Illinois Law Review 17-18.

51 In this context, market confidence means that 'it is safe' for investors to participate in a certain financial market. The importance of market confidence is fundamental in order to design a rationale for the regulation of CRAs.

52 Joshua D. Coval, Jakub W. Jurek and Erik Stafford, 'Economic Catastrophe Bonds' (2009) 99(3) American Economic Review 628-29. The authors observe that 'credit ratings describe a security's expected payoffs in the form of its default likelihood and anticipated recovery value given default. However, because they contain no information about the state of the economy in which default occurs, they are insufficient for pricing'. See also Joshua D. Coval, Jakub W. Jurek and Erik Stafford, 'The Economics of Structured Finance' (2009) 23(1) Journal of Economic Perspective 4-5.

53 Choi observes that 'conflicts of interest and agency cost problems within securities intermediaries are examples of problems with potential market-based solutions'. See Choi (n 40) 72. 
increase transparency in the financial markets by reducing the information asymmetry between issuers and investors. These concerns could determine a market failure if they are not adequately corrected by intervention on the part of the regulators.

1.20 The first of the aforementioned reasons for the inaccuracy of ratings, namely 'conflicts of interest', can be explained as a species of strategic behaviour in the issuer-credit ratings relationship and clearly emerges from the mechanism of the 'issuer-pays' model. The issuer fees characterize the compensation system. Thus, the most common conflict of interest lies in the revenue received by CRAs from the issuers that they rate. ${ }^{54}$ This scheme inevitably fosters an incentive to over-rate in order to secure a high fee and inflated ratings. A possible solution to this practice would consist in constraining rating fees. In order to mitigate this problem, it would be necessary to divorce issuer payment of the CRA from issuer selection of the CRA or encourage an alternative subscriber-pays market for ratings. ${ }^{55}$ In other words, a system of standardized revenues could be put in place in order to reduce reliance on the 'issuer-pays' business model. An 'investor-pays' model or 'subscriber-pays' model could be set up to address the question of conflicts of interest.

1.21 The second area-the lack of proper competition — that adversely affects the accuracy of ratings is better described by the fact that only three main CRAs (S\&P's, Moody's and Fitch) operate in the entire financial market. It is enough for one agency to become lax and unscrupulous in its rating activities for this to have negative consequences on the prediction of default events. Most investors rely heavily on these agencies, which makes for a de facto oligopoly and increases the chances of inaccuracy of forecasting. This problem is closely connected with the position and role of consumers (usually considered the weaker party to the transaction) because they are disadvantaged by the trading practices of suppliers. ${ }^{56} \mathrm{In}$ academic circles, a proposal has been made that competition should be encouraged by enacting an 'equal access' rule under which issuers would be required to disclose their data publicly. ${ }^{57}$ Part II of this book discusses whether the equal access approach would ensure greater competition among the main CRAs and incentivize smaller credit rating

54 Steven L. Schwarcz, 'Protecting Financial Markets: Lessons from the Subprime Mortgage Meltdown' (2008) 93(2) Minnesota Law Review 401. The author observes that 'rating agencies are customarily paid by the issuer of securities, but investors rely heavily on their ratings. This is technically a conflict, but it is not usually a material conflict because ratings are made independently of the fee received'.

55 Coffee Jr. (n 47) 49.

56 Joanna Benjamin, Financial Law (Oxford: Oxford University Press 2007) 563. The author argues that consumers are 'classes of person deemed to be economically weak'.

57 Coffee Jr. (n 47) 5. 
agencies to enter the US Nationally Recognized Statistical Rating Organization (NRSRO), a special designation body with functions of authorization, registration and control of CRAs.

However, fair competition limits the prices that suppliers can charge and therefore restricts their profits. It exerts pressure on them to reduce costs, thereby rendering the enterprise productively more efficient. It also obliges the suppliers to respond to consumer expectations about quality.

The third aspect, namely reluctance to make disclosure, was the third reason mentioned in connection with the inaccuracy of ratings. It is related to the 'appropriate' information disclosed by CRAs on their rating methodologies. This concern involves the risk of informational asymmetries between issuers and consumers. It is generally considered that this lack of equality in information disclosure - one of the principal causes of market failure ${ }^{58}$-brings about an imbalance of information between parties to trade (one so severe that exchange is impeded) and that its effects justify regulatory intervention by the institutions. In economic literature, informational asymmetries represent a situation where the capital receivers are in the position of having more knowledge about the prospects and condition of the corporation than the capital suppliers, and are thus in a position to abuse this advantage. ${ }^{59}$ There is an ensuing market failure in enhancing rating quality. This is due to a lack of competition and hence effective reputational discipline for getting it wrong.

It is manifest that the party with superior information about the probability of default can opportunistically use it to induce the other party (issuer) into unexpected and undesired outcomes. However, 'once the oligopolists' grip is loosened, there will be no shortage of analysts ready to take their place. Clients may hesitate to use unknown newcomers, but veterans of the big three should capture business'. ${ }^{60}$ Adequacy of disclosure is a gauge to determine what an investor knew or should have known, based on the information available to it. Public disclosure of rating procedures and historical performance data on accuracy should enhance transparency and comparability of ratings. As MacNeil has observed, 'enhancing transparency of rating information would

58 Bator (n 44) 351-52.

59 George Akerlof, 'Market for Lemons: Quantitative Uncertainty and the Market Mechanism' (1970) 84(3) Quarterly Journal of Economics 490; Hayne E. Leland and David H. Pyle, 'Informational Asymmetries, Financial Structure, and Financial Intermediation' (1977) 32(2) The Journal of Finance 371; Michael Rothschild and Joseph E. Stiglitz, 'Equilibrium in Competitive Insurance Markets: An Essay on the Economics of Imperfect Information' (1976) 90(4) Quarterly Journal of Economics 648; Joseph Stiglitz, 'Incentives, Risk and Information: Notes Toward a Theory of Hierarchy' (1975) 6(2) Bell Journal of Economics 552 .

60 'Redeeming Ratings' Financial Times (London, 10 November 2011). 
permit investors to look more closely into the "black box" of the rating process, thereby assisting them in understanding the ratings and facilitating due diligence on their own part'. ${ }^{61}$ In order to improve due diligence (for instance, investigations of the suitability of rating models), independent experts, such as compliance officers, could be appointed. This type of third party services could prove to be a strong incentive to issue accurate ratings.

1.24 A compliance department tasked with measuring the historical performance of ratings and verifying their methodologies could check the impartiality and independent approach of the relevant rating agency and disclose all information about rating procedures. In addition, the compliance officer could provide enhanced internal control mechanisms by ensuring that developments in the business and specific obligations satisfy the required standards of legality and integrity. ${ }^{62}$

In this regard, the establishment of an internal control mechanism for the ratings procedures could encourage companies to operate under market incentives such as transparency and fairness. In particular, an on-going compliance programme may resolve monitoring problems (e.g. when agents cannot verify a firm's monitoring ex ante). ${ }^{63}$ This type of regulatory approach should improve the governance of the CRAs and their legal duties to avoid and interdict the offences. This concept raises once again the thorny question of gatekeepers' liability in relation to their duties. ${ }^{64}$

1.25 In order to consider this concept, it is necessary to investigate the opportunistic behaviour of CRAs in respect of issuers because of their potential collusive actions. Further, this analysis aims to verify whether this collusive behavior faces a problem of cooperation, and whether that cooperation produces mutual gains for those who participate therein. ${ }^{65}$ The opportunistic behavior of rating agencies and issuers may be exacerbated by CRAs' governance where there are different parties with different interests in the outcomes of transactions. In order to tackle these issues, the research considers the implications of the

61 MacNeil (n 18) 200.

62 Caitlin M. Mulligan, 'From AAA to F: How the Credit Rating Agencies Failed America and What Can Be Done to Protect Investors' (2009) 50(4) Boston College Law Review 1300-01.

63 Jennifer Arlen and Reiner H. Kraakman, 'Controlling Corporate Misconduct: An Analysis of Corporate Liability Regime’ (1997) 72(4) New York University Law Review 766-67.

64 It has been observed that its enforcement potential depends not only on the offense and the level of culpability that triggers personal liability, but also on the choice of gatekeepers and upon the design of their duties'. On this point see Kraakman (n 8) 892.

65 This cooperative behavior is addressed by the 'repeated game theory' in which it is explained why people engage in actions which produce joint benefits greater than private costs in two-person relationships. See Eric A. Posner, Law and Social Norms (Boston: Harvard University Press 2000) 18. 
principal-agent theory so as to investigate the extent to which conflicts of interest and information asymmetries exist between the issuer, the ratings agency and investors. ${ }^{66}$

Assuming the principal-agent theory, ${ }^{67}$ this research explains how to recast the rating agencies-investors relationship. However, the issuer-agency relationship that exists between the issuer and the CRA raises questions from regulators and investors. ${ }^{68}$ In particular, issuers (principals) without sufficient information or expertise to implement their preferences employ agents (CRAs) who possess such expertise. Unless constrained (for example, by more focused regulation), agents may be able to exploit their discretion so as to advance their own interests, rather than those of their principal. Indeed, the agent may sacrifice the best interests of both investors and issuers for the agent's own personal self-interest. In this context, criticisms have arisen over the inability of CRAs to assess the market risk of structured financial products. ${ }^{69}$

A closer examination of the issuer-agency relationship enables some proposals to be advanced regarding the need of protection for consumers: the most effective way of solving the principal-agent problem in the credit rating sphere might be to realign the interests of the issuers and agencies. CRAs may be concerned to further their interests not only in relation to issuers but also to investors. The agency problem facing credit ratings is connected with the need of issuers to develop a reputation for credibility. Fully-informed investors should provide a natural disciplining influence on poorly-performing credit ratings.

66 Tony Van Gestel and Bart Baesens, Credit Risk Management (Oxford: Oxford University Press 2009) 124. In particular, the authors point out that 'the issuer credit rating is an overall judgement of the obligor's ability to meet his financial commitments. Issuer credit ratings reflect the issuer's fundamental credit risk, hereby making abstraction of security-specific differences related, e.g., to seniority, collateral, and/or guarantees'.

67 According to the economic literature, a principal-agent problem occurs when one individual engages a skilled person to undertake some profit-making, or other utility-conferring activity. Typically, because of the principal's lack of expertise, a significant incentive to interact in imperfectly competitive environments is conferred on the agent, with the risk that the latter may opportunistically exercise that discretion in a way which maximizes his or her own interests, rather than those of the principal. The regulation can constrain the relationship between principal and agent, but fails to prevent opportunistic behaviour. In other words, the principal-agent problem is intended as 'a contract that gives the agent the incentives to manage the asset in the best way for the principal'. See Robert Cooter and Thomas Ulen, Law E Economics (5th edn, Pearson International Education 2008) 147.

68 Gillian Tett, 'E-mails Throw Light on Murky World of Credit' Financial Times (London, 25 April 2010).

69 Committee on the Global Financial System, 'Ratings in structured finance: what went wrong and what can be done to address shortcomings?' (July 2008) Committee on the Global Financial System Papers No 32, $3-5$. 
Some commentators have argued that

gatekeepers [like CRAs] have an incentive to disappoint buyers only when the resulting gains exceed the costs of building a reputation. However, if sellers often find 'cheating' to be profitable, buyers will discount the value of the reputational signal accordingly — and in extreme cases, the reciprocal expectations that support reputation will collapse under the weight of moral hazard. ${ }^{70}$

Through their individual reputations, gatekeepers have the power to influence the product value and put pressure on the expectations of market participants. On this view, gatekeepers should be directly responsible to investors for their performance.

1.28 According to Coffee, the gatekeepers fail to report to a principal, which results in a situation of conflict of interests. ${ }^{71}$ In substance, the issuer wants the inflated rating less for its impact on the market than for its ability to reduce its regulatory costs. However, the issuer may misrepresent the information supply to the gatekeeper, but this misconduct could be detected or prevented by an internal supervisory body. In this way, the involvement of independent controllers should address the inaccuracy of ratings and limit the scope of conflicts of interest between issuers and raters.

1.29 The introduction of a strong 'principal' to monitor the 'agent' should cost little and produce quantifiable benefits. ${ }^{72}$ Under this regime, liability rules could furnish a powerful incentive to strengthen the screening accuracy of CRAs. ${ }^{73}$ In order to deal with these questions, it can be argued that an external supervisory body could certify both the accuracy of ratings assessments and the high quality of the financial product. Through this independent monitoring system, CRAs may signal their value to investors because the reputational value of CRAs depends on the level of their screening accuracy. Consequently, the supervisory body could play the role of a new 'agent' for the purposes of monitoring ratings. In addition, the supervisory body would have the incentive to control its agent (CRA) on grounds of consumer protection. This would

70 According to Kraakman (n 8) 97. The author observes that 'reputations are particularly important where buyers cannot verify the quality of goods or services prior to their purchases, and enforceable warranties prove costly or ineffective'.

71 Coffee Jr. (n 8) 335-37.

72 ibid 338 .

73 John C. Coffee Jr., 'Enhancing Investor Protection and The Regulation of Securities Markets' (2009) Columbia Law and Economics Working Paper No 348, 69. In particular, 'credit rating agencies must be compelled either to conduct reasonable verification of the key facts that they are assuming in their ratings methodology or to obtain such verification from professionals independent of the issuer'. For this obligation to be meaningful, it must be backstopped by a standard liability specifically designed to apply to credit rating agencies. 
realign the principal-agent relationship. Investors should become the principal who hires and fires the gatekeeper. In order to address these concerns, the concept of reputational capital ${ }^{74}$ is considered to explain the legal questions of CRA accountability.

\section{The reputational capital of CRAs}

CRAs have been accused of giving more weight to political rather than economic factors. They have also been accused of getting their timing wrong (for example, the warnings of downgrading of members of the Eurozone in the 2007-09 financial turmoil). ${ }^{75}$ In other words, CRAs have often been more successful at confirming risk but less good at risk prognosis. Policymakers' reliance on credit ratings increased during the current sovereign debt crisis (particularly during the Greek crisis in 2011-12), where rating downgrades led to market losses for countries, together with adverse effects such as the rapid drying up of liquidity. ${ }^{76}$

Credit rating firms have been criticized, not only for issuing inaccurate ratings to subprime mortgages ${ }^{77}$ thereby exacerbating the financial crisis, but also for weaknesses in their internal controls and procedures for managing conflicts of interest, including their corporate policies on securities trading. ${ }^{78}$ Empirical studies have shown internal control weaknesses in respect of corporate debt ratings. ${ }^{79}$ In this regard, a proposal has been made 'to establish an independent assessment institution to assess the accuracy of CRA estimates of probability of default, and to publish comparative studies of such accuracy'. ${ }^{80}$

74 The term 'efficiency' is identified in the sense of 'allocative efficiency' (i.e. the Kaldor-Hicks criterion). In the economic literature, the concept of efficiency can be regarded as the maximization of the wealth of society ('distributional efficiency') or 'allocative efficiency' (or 'Pareto efficiency') concerning the amount of welfare within a given society and an efficient policy is one which maximizes that amount (the satisfaction of individual preferences). A particular situation is 'Pareto efficient' where the benefit of one individual cannot be improved without reducing the benefit of any other member of society. See Richard A. Posner, Economic Analysis of Law (New York: Wolters Kluwer Aspen Publisher 2007) 11-15.

75 'S\&P Credit Warning Provokes Outrage' Financial Times (London, 7 December 2011) 7.

76 The current financial crisis has revealed the huge role played by CRAs in the rapid growth of structured products markets. In fact, structured products require a targeted rating that considerably involves the assessment process of credit agencies.

77 A subprime mortgage can be defined as a loan made to a borrower who has poor credit and would be disqualified from prime or near-prime mortgages. During the 2007-09 financial crisis, subprime mortgages assumed a significant role because the loans were bundled and sold as structured products called collateralized debt obligations. See Markus K. Brunnermeier, 'Deciphering the Liquidity and Credit Crunch 2007-2008' (2009) 23(1) Journal of Economic Perspectives 82-83.

78 Kara Scannell, 'SEC Critical of Rating Agency's Controls' Financial Times (London, 30 September 2011).

79 Samir M. El-Gazzar, Kwang-Hyun Chung and Rudolph A. Jacob, 'Reporting of Internal Control Weaknesses and Debt Rating Changes' (2011) 17(4) International Advances in Economic Research 421-25.

80 Charles A.E. Goodhart, 'How, if at all, should Credit Ratings Agencies (CRAs) be Regulated?' (June 2008) LSE Financial Markets Group Paper Series, Special Paper No 181, 25-26. See also Charles A.E. Goodhart, 
Notwithstanding some obvious benefits, a separately established independent authority would perhaps be too costly for the financial industry and would be less credible if it were to be directly controlled by the industry itself. In the well-known corporate scandals that engulfed Enron, WorldCom and Lehman Brothers, these companies were given high ratings and investors relied on them. For instance, the Enron case clearly illustrates the dangers of such reliance. ${ }^{81}$ The CRAs belatedly downgraded them but only after holding off for a time. Coffee observed that 'this pattern in which a ratings downgrade resembles more an obituary than a prophecy again suggests the absence of real competition'. ${ }^{82}$ Investors piled into these seemingly high-growth companies; the CRAs downgraded their ratings, red-flagging them as increasingly highrisk. ${ }^{83}$ This concern was considered to be negative by market participants because ratings changes appeared to be sluggish, inaccurate and with few incentives to be responsive to investors. ${ }^{84}$

1.32 CRAs have no incentives to screen the accuracy of their assessment methodologies. ${ }^{85}$ This stems from their performance with regard to the evaluation of financial-sector creditworthiness. The point is that rating agencies should establish a direct relationship with investors. These corporate scandals underlined the need for improving the working methodology of CRAs. They also drew attention to the fallibility of the CRAs' assessments, on which investors typically rely for protection without being conscious that they are disregarding the fact that a rating changes over time. ${ }^{86}$ For instance, in the Enron failure, gatekeepers certified the issuer's compliance with an inventory of highly technical rules-without the auditor necessarily taking responsibility for the

The Regulatory Response to the Financial Crisis (Cheltenham: Edward Elgar Publishing 2009) 129. In particular, the author suggests the establishment of a small independent body, a CRA Assessment Centre.

81 Jeffrey N. Gordon, 'What Enron Means for the Management and Control of the Modern Business Corporation: Some Initial Reflections' (2002) 69(3) University of Chicago Law Review 1234-35. See also Coffee Jr. (n 10) 1409-12.

82 Coffee Jr. (n 8) 285. The author observes that 'rationally, the nominal competitors may prefer to enjoy the quiet life and not invest in the personnel or monitoring necessary to detect financial decline before it becomes public knowledge'.

83 Andrew Hill, 'Enron: See No Evil, Hear No Evil, Speak No Evil' Financial Times (London, 2 December 2011) 19. The author observes that 'when the rating agencies downgraded Enron's debt to junk in late November 2001 (they had been holding off in the hope a rival group might buy the energy trader; many Wall Street analysts still rated the company a "buy" or "strong buy"), it was bust within days'.

84 William H. Beaver, Catherine Shakespeare and Mark T. Soliman, 'Differential Properties in the Ratings of Certified vs. Non-Certified Bond Rating Agencies' (2006) 42(3) Journal of Accounting and Economics 310-12.

85 Coffee Jr. (n 73) 66-67.

86 ibid 10-15. Coffee argues that two factors represent persuasive explanations for gatekeeper deterioration: (1) the rise of structured finance and the change in relationships that it produced between the rating agencies and their clients; and (2) the appearance of serious competition within the ratings industry that challenged the long stable duopoly of Moody's and Standard \& Poor's and that appears to have resulted in ratings inflation. 
overall accuracy of the issuer's statement of its financial position. ${ }^{87}$ It has been argued that 'the gatekeeper's services have value only if the gatekeeper is certifying compliance with a meaningful substantive standard'. ${ }^{88}$ In addition, the aforementioned corporate collapses (Enron, WorldCom, Lehman Brothers) raised questions about the conflict of interests that arises where CRAs perform consultancy work for their clients. ${ }^{89}$ In this regard, the securities industry has not settled the question as to whether CRAs should be liable for misrepresentations or fraud to issuers and investors.

Government initiatives (at the EU and US level) ${ }^{90}$ have sought to improve the transparency and fairness of CRAs by creating a rigorous system of regulation and supervision that enables the ratings industry to deliver services considered indispensable while, as far as possible, preventing them from pursuing activities that are deemed detrimental to consumers. ${ }^{91}$

The legal system set in place by the global regulators ${ }^{92}$ - IOSCO, Financial Stability Board (FSB), Group of Twenty (G-20) and Securities Industry and Financial Markets Association (SIFMA)—failed to create a harmonized normative framework for CRAs. This 'light touch' regime revealed weaknesses in addressing enforcement concerns. A further pertinent question is the scarce enforceability of the self-regulation regime governing the CRAs (in respect of principles, recommendations and codes of conduct delivered by global regulators). CRAs are like the gatekeepers of the capital markets, so it is very important to look for an appropriate regulatory response. ${ }^{93}$

As mentioned, ratings were under fire because of their inaccuracy in evaluating companies' creditworthiness and on account of the fact that the CRAs earned

87 See Coffee Jr. (n 10) 1416.

88 ibid 1417.

89 Stephanie Kirchgaessner and Kevin Sieff, 'Moody's Chief Admits Failure Over Crisis' Financial Times (London, 24 April 2010).

90 At EU level, see Regulation (EU) No 462/2013 (OJ 2013 L 146 p. 1). At US level, see the Dodd-Frank Wall Street Reform and Consumer Protection Act, P.L. 111-203 (Dodd-Frank Act 2010).

91 Gudula Deipenbrock and Mads Andenas, 'Regulating and Supervising Credit Rating Agencies in the European Union' (2012) 9(1) International and Comparative Corporate Law Journal 1.

92 Global regulators are generally considered 'informal regulators' since there is no formal legal framework that governs the responsibilities and the division of labour among them. These entities and bodies are involved in the process of setting international standards for financial markets commonly defined as a form of 'soft law'. See Mario Giovanoli, 'A New Architecture for the Global Financial Markets: Legal Aspects of International Financial Standard Setting' in Mario Giovanoli (ed), International Monetary Law. Issues for the New Millenium (Oxford: Oxford University Press 2000) 33. See also Chris Brummer, Soft Law and the Global Financial System, Rule Making in the 21st Century (Cambridge: Cambridge University Press 2012) 74.

93 Gilian Tett, Jennifer Hughes and Aline Van Duyn, 'S\&P unveils ratings overhaul' Financial Times (London, 7 February 2008). 
profits by selling regulatory licenses to issuers. ${ }^{94}$ Paradoxically, these profits did not reflect the informational value of the ratings. The problem was that the main CRAs had become more profitable even as the quality of their ratings collapsed. From this perspective, 'regulatory dependence on ratings created higher demand for ratings and increasingly higher profits for NRSROs (nationally recognized statistical rating organizations), even when their ratings proved spectacularly inaccurate'. ${ }^{95}$ For that reason, legitimate concerns have been raised about the regulatory reliance on ratings on the ground that it increases the incentives to shop for ratings. In this context, it may be noted that the reliability of CRAs is principally motivated by their experience and the reputation of rating agencies among investors. In fact, the gatekeeper is trusted to the extent that it is a repeat player who possesses significant reputational capital and information that would be lost or depreciated if it were found to have been involved in misconduct. In the result, the ratings market looks like an oligopoly with a small number of high profitable agencies that earn a consistently high rate of return.

This sort of oligopolistic market was boosted by the NRSRO's and the Securities and Exchange Commission's policy of entitling only selected rating agencies to assess issuers' bonds. However, this sort of oligopolistic position of the main CRAs 'seems attributable instead to the high barriers to entry into this market, which require that a new firm acquire reputational capital before it can acquire clients' ${ }^{96}$ As Coffee observed 'this lack of competition permits these nominal competitors to shirk, engaging in less effort and research than if there were true active competition'. ${ }^{97}$

1.35 The reputational capital of CRAs has constituted a wire fence with respect to investors and regulators creating a huge gap in the information supply process. The credibility of CRAs has progressively taken the place of regulatory interventions by financial institutions. ${ }^{98}$ In addition, the lack of a proper liability regime facilitates misstatements and negligence. These considerations

94 John Gapper, 'Let Rating Agencies Have their Say' Financial Times (London, 8 December 2011) 11, where it is observed that 'the agencies remain a protected species because central banks use ratings from officially approved agencies for purposes including deciding which collateral to take from banks and assessing the riskiness of assets'.

95 Partnoy (n 33) 190.

96 Coffee Jr. (n 47) 55.

97 Coffee Jr. (n 8) 285.

98 Mathias Audit, 'Aspects internationaux de la responsabilité des agences de notation' (2011) 100(3) Revue critique de droit international privè 582-85. 
underline the question as to whether CRAs should be subject to a system of civil liability. ${ }^{99}$

In the on-going debate, a model has been proposed which combines the better incentives of strict liability with a system that: (1) places a realistic ceiling on the gatekeeper's aggregate liability; and (2) minimizes the transaction costs associated with enforcement. ${ }^{100}$ This proposal subordinates compensation to deterrence, but only with regard to litigation against gatekeepers, who are seldom in any event in a position to fund full compensation to the class of investors and consumers. ${ }^{101}$

Another commentator has characterized ratings as a form of investment recommendations on the premise that 'de facto they may perform a similar function to recommendations by influencing (through regulatory and contractual linkages) the financial instruments that are held by financial institutions'. ${ }^{102}$ On this view, ratings should be subject to an equivalent regulatory regime to that to which investment recommendations are subject. However, the disclaimers often used by the leading CRAs (namely S\&P's, Fitch and Moody's) that ratings are merely simple opinions may constitute an obstacle to regulating the credit rating agencies as purveyors of recommendations.

A viable suggestion has been proposed by Partnoy on the basis that strict liability could be imposed on gatekeepers, such as CRAs, for material misstatements and omissions in offering documents while removing any due diligence-based defences from securities regulation. ${ }^{103}$ According to Partnoy, the advantage of imposing strict liability on gatekeepers would be that it would incentivize transparency and fairness. ${ }^{104}$ However, this would not afford a solution in terms of responsibility to investors, i.e. customers. A strict liability regime would be effective only with respect to the issuer, leaving the question of losses incurred by the investor unresolved. In addition, strict liability could

99 It may seem surprising because the rating agencies enjoy virtual immunity from private litigation. The recent cases have shown a reluctance to impose civil liability on CRAs. See, in particular, Jefferson County Sch. Dist. v Moody's Investor services, Inc. [1999] No 97-1157; Compuware Corp. v Moody's Investor services, Inc. [2007] No 05-1851; and Newby v Enron Corporation [2005] 511 F. Supp. 2d 741.

100 Coffee Jr. (n 21) 459. The author observes that strict liability coupled with a ceiling can produce adequate deterrence without necessarily exceeding the boundaries of political feasibility.

101 Frank Partnoy, 'Strict Liability for Gatekeepers: A Reply to Professor Coffee' (2003) University of San Diego School of Law, Law and Economics Research Paper, 3.

102 MacNeil (n 18) 197.

103 Partnoy (n 30) 540. According to Partnoy's proposal, a gatekeeper is strictly liable for a percentage of the securities fraud damages that the issuer pays. Partnoy also argues that 'the ex post costs of litigating securities disputes against gatekeepers would be almost entirely eliminated'.

104 ibid 542. 
be a potentially costly way of inducing gatekeepers to clamp down on client misconduct. ${ }^{105}$

1.38 According to Coffee's view, 'the gatekeeper could be held liable even when the issuer is not'. ${ }^{106}$ In particular, this perspective assumes that the gatekeeper has failed in his responsibility to unearth the irregularity and should not be absolved because the issuer's conduct was only negligent, rather than fraudulent. What is central to Coffee's position is the 'adverse selection' problem. This means that "if gatekeepers cannot distinguish ex ante the "honest" from the "dishonest" issuer, a lemons market developed under strict liability should logically drive the honest client from the market'. ${ }^{107}$

1.39 In economic literature, the theory of the 'lemons market' was developed by Akerlof in the early 1970s to exemplify the interaction of quality differences and uncertainty, in particular the presence of markets in which buyers use market statistics to judge the quality of prospective purchases. ${ }^{108}$ By taking as an example the model of the market in automobiles, this theory discusses the existence of the incentive for sellers to market poor quality merchandise, since the returns for good quality accrue mainly to the entire group (whose statistic is affected) rather than to the individual seller'. ${ }^{109}$ As Akerlof noted, the automobile market is preferred for its concreteness and ease in understanding rather than for its importance or realism. ${ }^{110}$

1.40 Therefore, a strict liability regime is justified only if it can address the CRA-investor relationship. Such a liability regime may go a long way towards remedying perceived negligence and poor services. ${ }^{111}$ This type of liability system may contribute towards the preservation of the CRAs' reputational capital: however, without specific legislation introducing such liability, it is hard to see how a case could be brought against the rating agencies for

105 Assaf Hamdani, 'Gatekeeper Liability' (2003) 77(1) Southern California Law Review 60. The author argues that 'holding gatekeepers strictly liable will not guarantee that clients enter the market only when it is socially desirable to do so'. Precisely, if strict liability is not superior in inducing gatekeepers to police client conduct, there is no justification for favouring it over other forms of liability (at 84). According to Hamdani's view, gatekeeper liability determines an inevitable trade-off between preventing misconduct and minimizing the disruption of market access. In these terms, no regime of gatekeeper liability is likely to produce the first-best outcome. This underscores the limited usefulness of gatekeeper liability as an instrument of social policy aimed at preventing misconduct (at 106).

106 See John C. Coffee Jr., 'Partnoy's Complaint: A Response' (2004) 84(2) Boston University Law Review 377-82.

107 ibid 380 .

108 Akerlof (n 59) 488.

109 ibid 488.

110 ibid 489

111 Mia Mahmudur Rahim, 'Credit Rating Agencies' Roles Have to be Reassessed' (2010) 4(4) Law and Financial Markets Review 435. 
liability. In this light, the ratings assessment could be more effectively regulated both through internal controls and hard-law measures. ${ }^{112}$ It can be observed that a mixed regime that includes elements of both liability and compliance activities could be a favourable one for CRAs. ${ }^{113}$ Such a mixed liability regime could improve the credibility (i.e. reputation) of CRAs by implementing measures such as monitoring, investigating and reporting misconduct. The key to a successful deal for a corporate issuer is securing the right credit rating. It is evident that companies and investment banks are not simply market-makers, or disinterested parties acting on behalf of clients. The interest to promote risky products and complicated financial schemes is the core business of securities' issuers.

In the US, an SEC investigation revealed that prominent investment banks had bundled 'toxic mortgages into complex financial instruments, managed to persuade the credit rating agencies to label them as "AAA" securities, and sold them to investors, magnifying and spreading risk throughout the financial system, and all too often betting against the instruments they sold and profiting at the expense of their clients'. ${ }^{114}$ What is more, one of the main players in the credit rating market was notified by the SEC that it could face civil charges on the ground that it had violated Federal securities laws in connection with its rating of a structured finance vehicle before the crisis. ${ }^{115}$

In substance, CRAs were accused of having made unrealistic assumptions about structured finance products in order to issue 'AAA' ratings. ${ }^{116} \mathrm{CRAs}$ claimed that their assessment does not explicitly address market pricing or

112 Rosa M. Lastra and Geoffrey Wood, 'The Crisis of 2007-09: Nature, Causes and Reactions' (2010) 13(3) Journal of International Economic Law 547-49. The authors identify 'five groups' of regulatory responses: (1) substance of regulation; (2) structure of supervision and regulation; (3) behaviour of the banking industry and bank managers; (4) fiscal side; and (5) bank structural reforms.

113 This analysis intends to extend the proposal argued by Arlen and Kraakman. See Arlen and Kraakman (n 63) 691-94. The authors suggest—in a corporate governance environment—a mixed entity liability regime that combines aspects of strict liability together with duty-based liability. In substance, this regime includes (1) modified forms of strict liability that are adjusted to induce firms to adopt policing measures and

(2) 'composite' liability regimes that combine monitoring and reporting duties with a residual element of strict liability to induce preventive measures and regulate activity levels.

114 United States Senate Permanent Subcommittee on Investigations, 'Wall Street and the Financial Crisis: Anatomy of a Financial Collapse' (13 April 2011) 6-7.

115 On 22 September 2011, The McGraw-Hill Companies, Inc. received a 'Wells Notice' from the Staff of the SEC stating that the Staff is considering recommending that the Commission institute a civil injunctive action against Standard \& Poor's Ratings Services, then a division of The McGraw-Hill Companies, Inc., alleging violations of federal securities laws with respect to S\&P's ratings for a particular 2007 offering of collateralized debt obligations, known as 'Delphinus CDO 2007-1'. See Kara Scannell and Shannon Bond, 'SEC in Court Threat to S\&P Over Financial Crisis' Financial Times (London, 26 September 2011).

116 Financial Crisis Inquiry Commission, 'The Financial Crisis. Inquiry Report', Final Report of the National Commission on the causes of the financial and economic crisis in the United States (January 2011). 
trading liquidity for the security in question, but rather focuses on the likelihood of a default.

1.42 Another question is that the few main CRAs provide ratings that have become too deeply embedded in the regulatory capital assessment system. Ratings are considered to be a measure of risk for regulatory capital, i.e. credit and market risk under the Basel framework, and their use influences the determination of capital requirements of financial firms. It is argued that 'the greater the leverage within those firms, the greater will be the effect of changes to ratings on capital requirements'. ${ }^{117}$ Many investors have mandates that only allow them to invest in securities that have a certain rating such as 'AAA'. It should be reiterated that the raison d'être of CRAs is to offer an opinion on the likelihood of debt instruments being repaid, which is a legitimate activity. Issuers pay for ratings because, in the long run, this deepens the pool of investors.

1.43 The underlying problem is how well CRAs fulfil their responsibilities. Rating agencies' activities suggest a clear degree of independence from issuers. The crux of the matter is 'because rating agencies make their rating determinations based primarily on information provided by the issuer of securities, a rating is no more reliable than that information'. ${ }^{118}$ It is clear that the 'certification' role of CRAs underlines the reliance which is placed on their gatekeeper function. Because CRAs influence market prices, not only in terms of disclosure information, but also in terms of outlooks, reviews and watches/warnings, CRA statements have impacted on investment grades.

1.44 An option to prevent CRAs exerting such power could be to stop promoting them or to motivate institutional investors to look for alternative sources of credit information. Such an option stems from the fact that 'the increased reliance on ratings reduced the reputational constraints on credit-rating agencies'. ${ }^{119}$ The prospect of this option coming to fruition could help to open the ratings market and stimulate the leading CRAs to improve their performances. Reputational capital and reputation alone are not a workable constraint on gatekeeper certification. It further postulates that it is necessary to bolster the ratings service with an independent oversight regime in order to help

117 MacNeil (n 18) 186.

118 Steven L. Schwarcz, 'The Role of Rating Agencies in Global Market Regulation' in Eilís Ferran and Charles A E Goodhart (eds), Regulating Financial Services and Markets in the Twenty First Century (Oxford: Hart Publishing 2001) 299.

119 Partnoy (n 35) 441. 
manage the complex global regulatory landscape and improve dialogue with investors, regulators and the public. ${ }^{120}$

Consumers are often unable to draw inferences about the reputation and reliability of the rating agency when an assessment takes place. CRAs should enhance the quality (and volume) of the information available to consumers. In other words, investors should be ensured of the appropriate level of information on which to base their decisions. Notwithstanding the quality of information, it is evident that some individual investors are unskilled and take poor decisions about risk even when they have full information about the products at their disposal. As a result, the question of the reliability of credit ratings and the influence of the main rating agencies constitute major areas of concern in the financial sector.

The CRAs fail to give a convincing answer to fundamental questions: to what extent do their activities contribute to market confidence and are indispensable to the growth of the financial sector? This latter question is a central one that this work addresses. The 2007-09 financial turmoil has provided much ammunition for opponents of the CRAs, but looking at the evolution of credit ratings the only surprise is that it took so long before any serious concern materialized.

As noted earlier in this Part of the book, securities regulation has recently sought to restore confidence in CRAs by striving to fill the major gaps in ratings' governance. The regulation centers chiefly on the conflicts of interest arising from the 'issuer-pays' model and the methodology and data sources used by CRAs. At the EU level, the European Commission set out a vast program to re-regulate the CRAs in which it sought to address the major concerns, such as the limited competition in the market for credit ratings, rating agency independence and the agencies' activities. ${ }^{121}$ As Moloney noted 'rating agencies can be regarded as pathfinders in terms of

120 Dalvinder Singh and John Raymond LaBrosse, 'Developing a Framework for Effective Financial Crisis Management', University of Warwick School of Law, Legal Studies Research Paper No 2012-05, 9.

121 European Commission, 'Proposal for a Regulation of the European Parliament and of the Council on amending Regulation (EC) No 1060/2009 on credit rating agencies', COM(2010) 289 final; European Parliament, 'Resolution of 8 June 2011 on credit rating agencies: future perspectives', (2010/2302(INI)) and Regulation No 513/2011 of 11 May 2011 amending Regulation (EC) No 1060/2009 on credit rating agencies. Also, the Commission issued a proposal amending Regulation (EC) No 1060/2009 (COM(2011) 747 final) and a proposal amending Directive 2009/65/EC on the coordination of laws, regulations and administrative provisions relating to undertakings of collective investment in transferable securities (UCITS) and Directive 2011/61/EU on Alternative Investment Funds Managers in respect of the excessive reliance on credit ratings (COM(2011) 746 final). 
operational harmonization, substantive harmonization, and the centralization of supervision'. ${ }^{122}$

1.46 The Commission proposed that issuers should be required to rotate the agencies that rate government bonds. ${ }^{123}$ The idea was to prevent the incumbent agency's analysts from becoming too 'overfamiliar' with issuers and therefore too lenient. In addition, the Commission proposed that issuers of financial products should be forced to change the rating agency they are using more regularly. This aimed to open up competition and avoid conflicts of interest. ${ }^{124}$

In this light, the reforms proposed conferred wide-ranging powers on the European Securities and Markets Authority (ESMA) to approve ratings methods and ban sovereign ratings in 'exceptional situations' (or in 'inappropriate moments'). ${ }^{125}$ Specifically, the ESMA is empowered to suspend the credit ratings of countries receiving emergency financial assistance. ${ }^{126} \mathrm{How}^{-}$ ever, it was claimed that 'any ability for ESMA to suspend sovereign ratings may damage the independence of the credit rating agencies in the eyes of the financial markets'. ${ }^{127}$

122 Niamh Moloney, 'Reform or Revolution? The Financial Crisis, EU Financial Markets Law, and the European Securities and Markets Authority' (2011) 60(2) International and Comparative Law Quarterly 525.

123 In particular, the EU proposal attempted to overhaul the ratings industry and force issuers to rotate the rating agency they use at least every three years, and in some cases every year. See Alex Barker, 'Rating Agencies Seek to Block EU Reform' Financial Times (London, 6 November 2011). The powerful lobbying deployed against similar proposals for auditing firms shows the sort of resistance that the Commission might expect also in the case of CRAs.

124 On 24 January 2012, the hearing held by the European Parliament's ECON Committee provided a comprehensive state of play of the positions on Credit Rating Agencies after the proposed draft regulation and directive on CRA III was adopted on 15 November 2011. The draft proposal had four main objectives: (1) to reduce over-reliance on ratings: the draft regulation requires the ESAs to reduce reliance on ratings when drafting technical standards and the draft directive addresses over-reliance from UCITs and AIFM; (2) to increase transparency on sovereign debt, with requirements regarding the frequency of ratings and on timing; (3) to enhance competition and reduce conflicts of interest, through the introduction of a rotation principle and of rules regarding cross-ownership; and (4) to introduce a civil liability regime for CRAs in case of gross negligence or intentional infringement of the Regulation. See European Parliament Committee on Economic and Monetary Affairs, 'Public Hearing on Credit Rating Agencies', Brussels, 24 January 2012.

125 According to Regulation (EU) No 462/2013 of the European Parliament and of the Council of 21 May 2013 amending Regulation (EC) No 1060/2009 on credit rating agencies (OJ 2013 L 146 p. 1), ESMA can conduct investigations, ongoing inspections and impose fines directly on credit rating agencies that breach European Union rules. See Nikki Tait, 'EU Body Empowered to Fine Rating Agencies' Financial Times (London, 3 December 2010).

126 Alex Barker, 'EU Shake-up for Rating Agencies' Financial Times (London, 20 October 2011).

127 AFME, 'AFME comment on the European Commission's proposals for Credit Rating Agencies' (Press Release, 16 November 2011), available at http://www.afme.eu. 
By the same token, it was proposed at the EU level that credit rating agencies could be barred from downgrading countries in the Eurozone bailout scheme. ${ }^{128}$ In this respect, if a CRA is described as a thermometer of financial crisis 'it is not the thermometer that causes the fever, but the thermometer has to work properly to ensure you do not exaggerate the fever'. ${ }^{129}$ However, the CRA issues ratings that are an ordinal measure of the creditworthiness of a debtor and this means that 'ratings are not temperature readings but weather forecasts'. 130

Some European countries have been extremely critical of the manner and timing of certain sovereign debt rating decisions taken during the 2010-12 Eurozone crisis, although the CRAs have defended their conduct. ${ }^{131}$ Other proposals included the establishment of a new independent ratings agency and different models to mitigate conflicts of interest in the current 'issuer pays' model. However, these proposals will more likely prove to be ineffectual because rating methods necessarily evolve over time to reflect innovations by underwriters, new legislation and changes in the financial market.

These proposals constituted the ground for the adoption of Regulation (EU)

No 462/2013. ${ }^{132}$ This legislation addressed two of the major concerns of the ratings industry: first, the near-total domination of the market by the main three rating agencies; and, second, the dubious issuers-rating agencies relationship. In this context, it should be noted that members of the European Parliament called on the European Commission to establish a public European CRA that would produce impartial ratings without being constrained by commercial considerations. ${ }^{133}$ The European Parliament also suggested looking at the possibility of establishing a network of smaller European rating

128 Eilís Ferran, 'Crisis-driven Regulatory Reform: Where in the World is the EU Going?' in Eilís Ferran, Niamh Moloney, Jennifer G. Hill, John C. Coffee, Jr (eds), The Regulatory Aftermath of the Global Financial Crisis (Cambridge: Cambridge University Press 2012) 13-14.

129 Michel Barnier, 'Commission Wants Better Quality Credit Ratings', European Commission, Press release, Brussels, 15 November 2011.

130 Dan Hanquist, 'The Importance of Being and of Being Earnest: Ontological, Epistemological and Constitutional Aspects of Credit Ratings' in Jan Kleineman, Lars Gorton and Aron Verstandig (eds), Perspectives on Credit Rating Agencies (Stockholm: Författarna, Stockholm Centre for Commercial Law och Jure Förlag AB 2013) 182. See in the same vein MacNeil (n 18) 179, footnote 3, where it is observed that 'ratings provide an ordinal measure which does not seek to measure the distance between two variables. The medals awarded in the Olympic Games are a classic example'.

131 Alex Barker, 'A Glimmer of Hope for Credit Rating Agencies' Financial Times (London, 11 November 2011).

132 Regulation (EU) No 462/2013 of the European Parliament and of the Council of 21 May 2013 amending Regulation (EC) No 1060/2009 on credit rating agencies (OJ 2013 L 146 p. 1).

133 European Commission, Public Consultation on Credit-Rating Agencies, 5 November 2010. See also Geraldine Lambe, 'CRA: Regulation with Bite or Toothless?' The Banker (London, June 2011). 
agencies, in an effort to bring more competition into the industry. ${ }^{134}$ But the former proposal had already been greeted with a considerable amount of scepticism, not least because of the perceived lack of independence of such an agency.

1.49 Concerns about rating 'downgrading' have made CRAs unpopular, in particular on account of the inconvenient timing of their published opinions. ${ }^{135}$ Financial institutions are still searching for an appropriate solution for a modus operandi of CRAs. However, criticisms of rating agencies are entirely legitimate where their predictions seem to suggest that they may be motivated by some speculative intent. ${ }^{136}$ Moreover, speculation about rating agency downgrades of countries' sovereign debt influences trading on the markets. Notwithstanding this, the main rating agencies claim that this is an inevitable consequence of issuing independent opinions, and that opinions are only one measure of risk. Downgrades are not only a reflection of reality but also a provision of ground-breaking new information about the speculative effects of the downgrades on the markets. CRAs should face a lagging indicator rather than a leading one. They should verify the market's judgement rather than lead it.

1.50 Cantor and Mann have argued that there is a trade-off between rating evaluations and market stability. ${ }^{137}$ Empirical studies have identified that the focus of agencies on long investment horizons explains only part of the relative stability of agency ratings. ${ }^{138}$ Further, other academic studies have shown a possible balance between rating stability, rating timeliness and default prediction performance. ${ }^{139}$

If the role of CRAs is solely to forecast the creditworthiness of financial instruments, it is possible to point to an imbalance between downgrade

134 Nikki Tait, 'Brussels Faces Rating Agency Dilemma' Financial Times (London, 7 July 2011).

135 As the EU Commissioner for Internal Market and Services, Michel Barnier, noted, 'I have also been surprised by the timings of some sovereign ratings — for example, ratings announced in the middle of negotiations on an international aid programme for a country'. Barnier also claimed that 'Ratings have a direct impact on the markets and the wider economy and thus on the prosperity of European citizens.' 'They are not just simple opinions.' See BBC, 'EU Targets Credit Rating Agencies', 15 November 2011, available at http://www.bbc.co.uk/news/business-15739234.

136 Bo Becker and Todd Milburn, 'How Did Increased Competition Affect Credit Ratings?' (2009) Harvard Business School, Working Paper No 09-051, 10.

137 Richard Cantor and Christopher Mann, 'Analyzing the Tradeoff Between Ratings Accuracy and Stability' (2007) 16(4) The Journal of Fixed Income 60-64.

138 Edward I. Altman and Herbert A. Rijken, 'How Rating Agencies Achieve Rating Stability' (2004) 28(11) Journal of Banking and Finance 2679-80.

139 Edward I. Altman and Herbert A. Rijken, 'The Effects of Rating Through the Cycle on Rating Stability, Rating Timeliness and Default Prediction Performance' (2005) New York University Working Paper No FIN-04-032, 26-27. 
evaluations and market confidence. As Coffee observed 'as gatekeepers, the credit rating agencies did not monitor clients closely after the point of their initial rating. Thereafter, rating downgrades generally followed the market, rather than led it'. ${ }^{140}$ One key concern is whether rating downgrades may destabilize financial markets, particularly when downgrades cross into noninvestment grade categories. As indicated earlier, the information provided by CRAs is regarded as being a public good. Consequently, CRAs should supply information freely, not only to issuers who have paid for it (and can benefit from this information), but also to investors that rely on it.

By keeping a record of the outcome of their rated instruments, CRAs provide a public service. It has been argued that 'a rating is valuable only if everybody knows it, and you cannot get an investor to pay for information he already has. Ratings are a public good that have two possible paymasters: government or issuers'. ${ }^{141}$ Since regulators use them, regulators could pay for the use of CRAs' information. CRAs have become private regulators of international capital markets, it is evident that the importance of ratings for the assessment of credit risk is enhanced by the regulatory use of these assessments. Investors - as market participants — should be made aware of the uncertainties surrounding future predictions of default events. So there is a public interest in generating accountability for this publication of results.

The reluctance of CRAs to adjust the ratings of those products to reflect the value of the underlying assets (in particular following an upward spiral in subprime mortgage defaults) seems to distort the markets and create an imbalance of information for investors that rely on the accuracy and transparency of the supplied service. Investors have become dependent on ratings and 'the CRAs decision making constitutes a black box, the consequences emanating from that black box are of crucial importance for issuers' ${ }^{142}$ The idea of rating as public good is centered on the need to protect the benefit of the investing public. CRAs should be independent financial intermediaries while they perform the role of purveyors of stamps used to access the capital markets.

140 Coffee Jr. (n 8) 324-25.

141 Avinash Persaud, 'The Right Direction for Credit Rating Agencies' Financial Times (London, 18 October 2007).

142 Fritz Sager and Markus Hinterleitner, 'How Do Credit Rating Agencies Rate? An Implementation Perspective on the Assessment of Austerity Programs during the European Debt Crisis' (2016) 44(4) Politics E Policy 788. 


\section{Structure of the book}

1.53 This work discusses the weakness of the present regulatory regime for CRAs and examines some viable changes designed to enhance the accuracy of ratings and encourage the disclosure of information. In this regard, it is argued that the lack of care shown in the CRAs' activities is such as to cause damage to the financial market whenever their 'predictions' are not accurate. Indeed, the CRAs seem to respond more receptively to political concerns and to those of lobbies. ${ }^{143}$

This work also attempts to demonstrate that there is a need for an external body with the function of monitoring the accuracy of CRAs' opinions of default events. ${ }^{144}$ CRAs usually rate the credit default risk of the assets to which they give a particular rating. This aspect has been misinterpreted because a rating covers market and liquidity risk as well. Regulators could require the financial industry to standardize what ratings mean, instead of every ratings agency having its own particular interpretation of ratings.

1.54 In order to address these questions, it is assumed that a structural reform of CRAs' internal governance is required. Thus, the investigation seeks to demonstrate that reform of the CRAs is to be preferred over free market solutions that permit anyone to issue credit ratings and anyone to rely on them. ${ }^{145}$ In particular, the analysis proposes a new accountability approach in which CRAs are subject to closer regulation and a liability regime. Consequently, the arguments presented define a regulatory environment in which credit rating agencies can play a useful and efficient role as informational intermediaries. Deeper CRA analysis can be expected to show the nature of the interaction (or cooperation) between rating agencies and issuers. This would ascertain whether these groups cooperate to maximize their joint profits regardless of consumers. The aim is to provide suggestions for keeping the effectiveness of the CRAs' work and the protection of investors aligned. The ultimate aspiration is that people who pursue profits at the same time benefit the public.

1.55 The analysis of the role of CRAs is designed to facilitate understanding of what kind of regulatory tools are needed for CRAs. Once again, incomplete information is the central problem of the rating agencies/investors relationship. However, another question is to understand how these parties bargain

143 Philip Stephens, 'Downgrade the Rating Agencies' Financial Times (London, 20 January 2012).

144 Goodhart, The Regulatory Response to the Financial Crisis (n 80) 121.

145 The analysis intends to extend the point made by Coffee. See Coffee Jr. (n 47) 5-6. 
with one another and the way in which they allocate the information. It is important to note that adequate investor protection against market distortions requires trustworthiness and reliability. ${ }^{146}$

In order to avoid failures on the part of CRAs, it is necessary that those agencies should perform their role of promoting financial awareness by being accountable for their opinions. This is especially the case as they are indeed more than simple opinion providers. The scholarly opinion and case law rely strongly upon US law on the one hand (with numerous references to the securities laws which have been influential for the development of credit rating agencies) and European law on the other hand (with references to the various pieces of legislation that regulate the credit rating sector) as well as specific UK and Australian law.

This book is structured as follows. Part I provides an overview of the ratings environment and describes the role of CRAs in the securities markets. The increasing influence of CRAs in the securities sector and their operationswith particular emphasis on certain drawbacks in the current regulatory framework - as well as the longstanding problems associated with the CRAs' activities, is considered. This Part discusses the reliability of CRAs, since this has been questioned following the mis-evaluation of the default risk attaching to certain financial products - such as subprime mortgages and derivativesthat adversely affected the stability of securities markets. It also conducts an investigation in terms of the observable differences in the rating agencies' characteristics. A probable development of regulation draws on this investigation. The research on this aspect provides evidence into aspects such as: (1) the motivation of CRAs to issue solicited or unsolicited ratings; (2) the discretion of CRAs to bring into play evaluation models and to control the treatment of information; and (3) the assessment of rating agencies' responsibility. The results are interpreted with regard to the standard of rating activity, evaluating positive and negative effects of adopted regulation. This analysis offers significant implications with regard to an applicable normative framework. It is argued that CRAs exhibit potential conflicts of interest because they have a financial incentive to accommodate the preferences of bond issuers owing to the fact that they are selected and paid for by them.

146 According to the economic literature, market distortions could be determined by phenomena such as moral hazard and adverse selection. Moral hazard occurs in the insurance sector when the behaviour of the insuree changes after the purchase of insurance so that the probability of loss tends to increase. So "where one party to a transaction may undertake certain actions that affect the other party's valuation of the transaction but the second party cannot monitor or enforce perfectly'. Vice versa, adverse selection occurs where 'one party to a transaction knows things pertaining to the transaction that are relevant to but unknown by the second party'. See Kreps (n 41) 577. 
1.57 This Part also discusses how CRAs' activities have exhibited a lack of due diligence and a deficiency in their assessment of corporations' creditworthiness. It also focuses on the 'certification role' of CRAs, with particular attention given to criticisms of the ratings market. In this context, the function of 'rating triggers' is examined and the major problems regarding their use in financial contracts. The role of rating triggers in financial transactions is addressed by considering the main criticisms of the effects of such clauses on market participants (such as the lack of disclosure of the triggers in contracts). The problem of over-reliance on credit ratings is considered by taking into account the possible presence of 'unhelpful' incentives in the CRA industry. The question of free-market interference is discussed in terms of facilitating a systematic dependence on ratings and favouring an artificially high demand for highly rated financial instruments.

1.58 In the second part, the focus is on the regulatory framework of CRAs, with particular attention being paid to the existing legislation at the global level and in the US, the UK and the EU. These securities markets designate specific rules that are intended to improve disclosure and set forth a stringent regime for CRAs. It considers how harmonized rules could eliminate differential treatment under the law and introduce on-going supervision with accountable responsibility for rating agencies. However, methods for securing more cooperation among global regulators, with a system of integrated controls, are also considered. Such methods could require the disclosure of all aspects of the ratings activity, with an emphasis on the evaluation methods and enhancing the transparency of information.

1.59 The original contribution is the design of a regulatory framework to make CRAs accountable while proposing concrete solutions to the problems of information asymmetries and conflicts of interest between issuers and investors. The idea is that CRAs should be made responsible for their investment certification because of their fundamental role in the evaluation of credit risk in influencing investors' confidence. This Part examines the CRAs' regulatory reforms relating to CRAs that have been adopted in the US, the UK and the EU. It imparts the major concerns associated with the CRAs' assessment activity. It is contended that government initiatives have restored the transparency and fairness of CRAs by creating a rigorous system of regulation and supervision. However, the success of these regulatory measures is disputed. On this view, it is observed that the legal system set in place by the global regulators, ${ }^{147}$ namely FSB, G-20, IOSCO and the Basel Committee on

147 In the international financial architecture, global regulators developed a number of policies, practices, standards, and codes of good practice that can be characterized as soft law. The current activity of the 
Banking Supervision (BCBS), failed to establish an adequate regulatory framework for CRAs.

Part III discusses the different options to hold CRAs liable in the UK such as contract, tort, fiduciary duty, estoppel and statutory right of action. It focuses on the legal reasoning by which liability might attach to a CRA and identifies the parties who might have a claim and the nature of the damages that might be recovered. CRAs are professional financial intermediaries and their ratings are qualified statement of facts that carry with them liability when they are inaccurate.

In Chapter 7, the 'estoppel doctrine'-specifically estoppel by representation (or estoppel by conduct) - is considered as a possible option to hold CRAs liable for inaccurate ratings together with an analysis of the liability scenario under the law of tort. If estoppel is used to protect persons who reasonably and detrimentally rely on the representations of others, CRAs should owe a duty to take reasonable care that the statement is correct. However, it is a difficult task for investors to show that their expectations were affected by inaccurate ratings at the time when the investment decision was taken. In other words, once the representation has been acted on to the detriment of the transferee the contrary may not be asserted. Estoppel by representation may be applied where CRAs might seek to deny their evaluations in case of faulty ratings. Further, estoppel by representation may be used as an argument to demonstrate that the rating represented an informed statement of fact based on internal methodologies upon which investors relied; and to prevent the CRAs from claiming that rating is a mere opinion about the creditworthiness of financial products.

This Part considers the implementation of the liability regime in the US (Chapter 8), the EU (Chapter 9) and Australia (Chapter 10). This Part also explains why and how each system arrived at its own solution. In this regard, it provides critical reflections of Australian case law, namely the Bathurst judgment, and an assessment of the civil liability regime for CRAs established by the EU regulatory framework.

financial markets has permitted the adoption of new methods of regulation characterized by informal rules and sectoral normative instruments. As Lastra argued 'soft law is informal law. Its main problem is enforcement. Its main drawback is legitimacy. Its greatest advantage is flexibility. Soft law fills a need, a legal vacuum in the regulation of cross-border banking activities. It cannot therefore be dismissed'. See Rosa M. Lastra, International Financial and Monetary Law (Oxford: Oxford University Press 2015) 554. 
Part IV provides concluding observations along with a summary of presented policy and regulatory recommendations for reforming the rating industry. 